\title{
El GRC: Material compuesto de matriz inorgánica reforzado con fibras de vidrio AR
}

\author{
GRC: Composite material from an inorganic matrix reinforced \\ with AR glass fibres
}

Fecha de recepción: 2-V-96

Fecha de acoptación: 31-V-96
P.I. COMINO ALMENARA

VETROTEX ESPAÑA, S.A. - Product Manager Cem-FIL, Madrid

ESPAÑA

\author{
RESUMEN \\ En este artículo se detallan cuáles son las bases históricas de \\ las Fibras de Vidrio Alcali-Resistentes Cem-FIL asi como las \\ caracteristicas del elemento compuesto que ellas generan: \\ GRC. En este documento también se pueden encontrar \\ indicaciones sobre las principales ventajas y propiedades de \\ este tipo de Material Compuesto.
}

\section{SUMMARY}

This article describes the historical background of ('em-lill. Alkali Resistant Glass Hibre, as well as the composite characteristics of the element they generate: GRC'. The most important advantages and properties of this type of ('omposite Material are also detailed.

\section{1.- INTRODUCCIÓN}

Podríamos definir los Materiales Compuestos como aquellos que se obtienen mediante la unión de diferentes materiales, los cuales, de forma individual, presentan inferiores características mecánicas, físicas o químicas de las que presenta el conjunto del Material Compuesto que generan. Es, pues, el Material Compuesto un elemento fabricado expresamente para mejorar los valores de las propiedades que los materiales constituyentes presentan por separado.

Los materiales compuestos generados por las Fibras de Vidrio Alcali-Resistentes AR, son composites ampliamente conocidos en el mercado mundial con e! nombre de GRC. Veremos lo que estas siglas significan así como la historia, propiedades y principales aplicaciones de las Fibras de Vidrio AR Cem-FIL y de los elementos compuestos que se generan a partir de ellas.

\section{INTRODUCTION}

Composite Materials may be defined as those obtained by joining together diverse materials which individually have inferior mechanical, physical or chemical characteristics than those of the set of Composite Material they generate. Thus, a Composite Material is an element manufactured expressly to improve the values of the properties' of the individual materials forming it.

The composite materials generated by Alkali-Resistant (AR) (ilass Fibre are composites that are well known on the world market under the name of ( IRR : Wie shall now see the meaning of this acronym and its history: as well as the properties and main applications of such fibres and the composite elements generated from them. 
GRC (nombre comercial con el que se conocen a los Hormigones compuestos por morteros de cemento reforzados con Fibras de Vidrio Álcali Resistentes), son siglas que identifican el producto por su denominación inglesa "Glass Fibre Reinforced Cement", es el resultado de numerosas investigaciones y aplicaciones de diferentes productos en la historia de los Materiales Compuestos para la construcción.

\section{LA FIBRA DE VIDRIO AR}

\subsection{Su historia}

Las Fibras de Vidrio AR (alcali-resistentes) presentan altas prestaciones para el refuerzo de morteros de cemento, hormigones y, en general, piezas que puedan verse sometidas al ataque de tipo alcalino.

En búsqueda de un refuerzo que permitiera la consecución de un Material Compuesto de matriz inorgánica, robusto y con excelentes prestaciones, se han desarrollado numerosas experiencias con otras fibras de refuerzo tales como las de origen orgánico (aramidas, nylon, rayon, polipropileno,...), inorgánico (vidrio, boro, carbono, ...) y metálicas (hierro, fundición dúctil, acero, $\mathrm{Ni}, \mathrm{Ti}, \mathrm{Al}, \ldots)$. De entre todas ellas, la mejor relación coste-propiedades mecánicas la ostentan las Fibras de Vidrio, ofreciendo una gran facilidad de trabajo y manejabilidad, conjugada con un carácter inocuo y seguro, otorgando a los Materiales Compuestos, generados con ellas, grandes resistencias mecánicas. Los primeros ensayos y experiencias para el refuerzo de los cementos y sus morteros se realizaron con Fibras de Vidrio tipo "E" (usadas normalmente para el refuerzo de plásticos y poliésteres), dada la alta resistencia inherente de las mismas. Sin embargo, dichas tentativas fracasaron debido a que, este tipo de Fibra de Vidrio, al ser incorporada al mortero, estaba sujeto al ataque químico de los cristales alcalinos (álcalis) producidos en el proceso de hidratación del cemento, sin poderse remediar este problema.

En 1967 el Dr. A.J. Majundar, del Building Research Establishment (BRE) del Reino Unido, empezó a investigar los vidrios que contenían Circonio, logrando convertir en fibra alguno de ellos y demostrando la resistencia que presentaban estas fibras ante el ataque alcalino en un medio agresivo como el que suponía el refuerzo de los cementos Portland. Tras varios años de continuas investigaciones el refuerzo duradero para los cementos se logró y la patente de esta investigación fue solicitada por el National Research Development Corporation (NRDC).

Para la producción a escala comercial, el NRDC y BRE contactaron con la empresa inglesa Pilkington Brothers
GRC (the commercial name given to the concrete comprised of cement mortars reinforced with Alkali Resistant Glass Fibres) identify the product known under the English name of "Glass Fibre Reinforced Cement", the result of much research and applications of different products in the history of Composite Materials for building.

\section{AR GLASS FIBRE}

\subsection{Its history}

Alkali Resistant (AR) Glass Fibre provides high reinforcement levels in cement mortars, concrete and in general, pieces that may be subject to any kind of alkali attack.

The search for a reinforcement that would allow a composite material to be obtained from an inorganic matrix, be robust and have excellent features brought about development of other reinforcement fibres, such as those of organic origin (aramides, nylon, rayon, polypropylene, ...), inorganic (glass, boron, carbon, ...) and metallic ones (iron, draw casting, steel, Ni, Ti, Al. ...). Among all these, the best cost to mechanical property ratio is obtained from Glass Fibre, which is most easy to work with and handle, in addition to it being unhazardous and safe, providing the composite materials made with it great mechanical resistance. The first trials and experiences of reinforcement for cement and mortars were performed with type " $E$ " glass fibre, (normally used to reinforce plastic and polyester) due to its high inherent resistance. However. this failed as, when that type of glass fibre was mixed with the mortar, it came under chemical attack from the alkaline crystals (alkalis) produced in the process of hydrating the cement and no solution could be found to that problem.

In 1967. Dr. A.J. Majundar, from the Building Research Establish (BRE) in the United Kingdom began to research into glass containing zirconium and managed to turn some into fibre, demonstrating their resistance to alkali attack in such an aggressive environment as Portland cement reinforcement. Over several years of continuous research to find a lasting reinforcement for cement, which was achieved and the patent of this research was applied for by the Vational Research Development (orporation (NRI)(').

T'o set about large scale production, the NRI) ' and BRE contacted an English firm, Pilkington Brothers 
(PLC), quien, con su Compañía subsidiaria Fibreglass Limited, desarrolló la explotación, industrial y comercial, del producto al que llamaron Fibras CemFIL. En 1989, la Actividad de la Fibra de Vidrio Alcali-Resistente Cem-FIL fue adquirida por el Grupo Saint Gobain por medio de su filial en España, Cristalería Española S.A., y explotada por la Empresa Vetrotex España S.A., que forma parte de este gran Grupo.

Vetrotex España S.A., en su fábrica situada en Alcalá de Henares, es líder mundial en la fabricación de este tipo de Fibra de Vidrio, exportándola a todos los países del mundo, cerrando con este producto una gran gama de Fibras de Vidrio que la convierten en líder indiscutible del mercado mundial en este Sector Industrial

\subsection{Su fabricacion}

Como principal materia prima en la fabricación de un GRC, se emplean las Fibras de Vidrio Alcali-Resistente Cem-FIL, mediante las cuales el GRC logra las características que se van a detallar en este estudio.

En el Vidrio Alcali-Resistente el componente "estrella" que otorga a la fibra su poder de Alcali-Resistencia es el Circonio $(\mathrm{Zr})$.

El proceso de fabricación de la fibra de vidrio AR-CemFIL sigue las siguientes etapas:

\section{Composición-Fusión}

Las materias primas, finamente molidas, se dosifican con precisión y se mezclan de forma homogénea.

A continuación, la mezcla, llamada vitrificable, es introducida en un horno de fusión directa y calentada a una temperatura determinada. Estas condiciones imponen, a la hora de la construcción del horno, la utilización de refractarios de características específicas a base de óxidos de circonio y cromo, de coste muy elevado.

\section{Fibrado}

El vidrio, en estado fundido, al salir del horno, es conducido por unos canales (Feeders), alimentando las Hileras de Fabricación de fibras. Estas hileras son elementos fabricados con aleaciones de Platino, de forma prismática y con la base trabajada con un número determinado de agujeros de dimensiones controladas. La distribución y diseño de los agujeros es tal, en la hilera, que permiten y facilitan el fibrado del vidrio.
(PLC) , which developed the industrial and commercial operation of the product through its subsidiary

Fiberglass Limited, naming it Cem-FIL Fibres. In 1989, the activity of Cem-FIL Alkali Resistant Glass Fibre was acquired by the Saint Gobain Group through its subsidiary in Spain Cristaleria Española, S.A. and operated by the Company Vetrotex España, S.A. which is part of that large Group.

Vetrotex España, S.A. 's factory in Alcalá de Henares is the market leader in the world producing this glass fibre, which it exports all over the World, as this product completes the great range of fibre glass, making it unarguably a leader on the worldwide industrial sector market.

\subsection{Manufacturing}

The main raw material to manufacture a GRC is CemFIL Alkali Resistant Glass Fibre, through which the (iRC obtains the characteristics described in this study.

The "star" component in the Alkali Resistant Glass that provides the fibre its Alkali Resistant power is Zirconium (Zr).

The AR-Cem-HIL manufacturing process takes place in the following stages:

\section{Composition-Fusion}

The raw materials, finely ground, are precision dosed and mixed homogeneously.

The mixture, called vitrifiable, is then placed in a direct fusion oven and heated to a specific temperature. Such conditions require the oven to be built with specific refractory brick characteristics, based on zirconium and chrome oxides, at a very high cost.

\section{Forming Area}

When the molten glass leaves the oven, it is drawn through channels (leeders) to the fibre bushing lines: These lines are components manufactured with prism shaped platinum alloys, the base of which contains a set number of holes of specific sizes. The distribution and design of the holes is such that the line allows and facilitates drawing the glass. 
El vidrio fundido se mantiene en la hilera a una temperatura que permite su colada por gravedad, dando origen a barras de vidrio de algunas décimas de milímetro de diámetro. A la salida de la hilera, el vidrio se estira a gran velocidad, según el micraje de fibra a fabricar (diámetro a obtener). Para la obtención del vidrio como tal y tras el estado fundido, se procede a un rápido enfriamiento del vidrio fibrado.

El vidrio obtenido tras este proceso tiene forma de filamento de varias micras de diámetro. Para el vidrio AR Cem-FIL, los diámetros normales de filamentos oscilan entre las 14 y las $20 \mu$ (micras) según el producto y la aplicación a la que se dirija.

\section{Ensimado}

El conjunto de filamentos desnudos, tal y como salen de la hilera, son inutilizables directamente, ya que no hay cohesión entre ellos, no resisten la abrasión, carecen de flexibilidad y trabajabilidad, etc...

Para corregir estos defectos y dar nuevas propiedades a la fibra en función de su aplicación, así como para poder transformarla y trabajarla en su fabricación y presentación comercial, es necesario revestir los filamentos con una fina película (ensimaje) que está constituida, en general, por una dispersión acuosa de diversos compuestos químicos que presentan una función bien definida.

Inmediatamente después de la ensimación se procede a la unión de los filamentos, para formar los hilos o conjunto de filamentos, dispuestos en formato comercial.

\section{Bobinado}

Los hilos obtenidos de la unión de los filamentos son bobinados para dar lugar a productos finales ( Roving Directo ) o productos intermedios ( Ovillos ), que se bobinan según diferentes formas y geometrías.

Será en el proceso de bobinado donde se controlará la velocidad de rotación de la bobinadora y, por tanto, la velocidad de estirado de la fibra de vidrio.

\section{Secado}

Los productos procedentes del bobinado se pasan por diferentes dispositivos de secado con objeto de eliminar el exceso de agua en el que se había disuelto el ensimaje y otorgar al ensimaje un tratamiento térmico, necesario para consolidar sus propiedades frente a las aplicaciones a las que será destinado.
The molten glass is kept in the line at a temperature which allows it to sieve through by gravity, forming bars of glass a few tenths of a millimeter in diameter. At the exit from the line, the glass is drawn out at great speed, according to the micron measurement of the fibre to be manufactured (diameter to obtain). To obtain glass as such after the molten state, the glass fibre is rapidly cooled off.

The glass obtained from this process is in the form of a filament several micron in diameter. The normal diameters of AR Cem-FIL glass filaments lies between 14 and $20 \mu$ (microns), depending on the application it is intended for.

\section{Size application:}

The set of bare filaments, just as they leave bushing, are not directly usable, as there is no cohesion between them, they do not resist abrasion, lack flexibility, workability, etc...

To correct these defects and provide the fibre new properties depending on the application intended, as well as to be able to transform it and work with it in manufacturing and commercial presentation, it is necessary to coat the filaments with a fine film (size) which is generally comprised of a water based spray of diverse chemicals to provide a well defined function.

Immediately after size application, filaments are joined to form the threads or set of filaments laid out in commercial format.

\section{Winding}

The threads obtained by joining the filaments are wound to form the final products (Direct Roving), or intermediate products (Cakes), which are wound in different forms and geometries.

The winding process is when the winder rotation speed, and thus the stretch speed of the glass fibre is controlled.

\section{Drying}

The products from winding run through various drying devices in order to eliminate the excess water dissolved during size application and to provide the size thermal treatment required to consolidate its properties for the applications to which it will be submitted. 
Transformación final

En la transformación final se realizarán las operaciones necesarias encaminadas a conferir al hilo el formato adecuado para la correcta utilización por parte de los Fabricantes de GRC. De esta forma, las principales presentaciones comerciales actuales del Vidrio ÁlcaliResistente Cem-FIL son el roving ensamblado y los hilos cortados.

En la Figura 1 se representa, de forma esquemática, el proceso de fibrado del vidrio anteriormente descrito.

\section{Final transformation}

During the final transformation, the necessary operations are performed for the thread to obtain the right format for correct use by GRC manufacturers. Thus, the present commercial formats of Cem-FIL Alkali Resistant Glass Fibre are chopping roving and the chopped strands.

Figure I is a scheme of the glass fibre forming process described above.

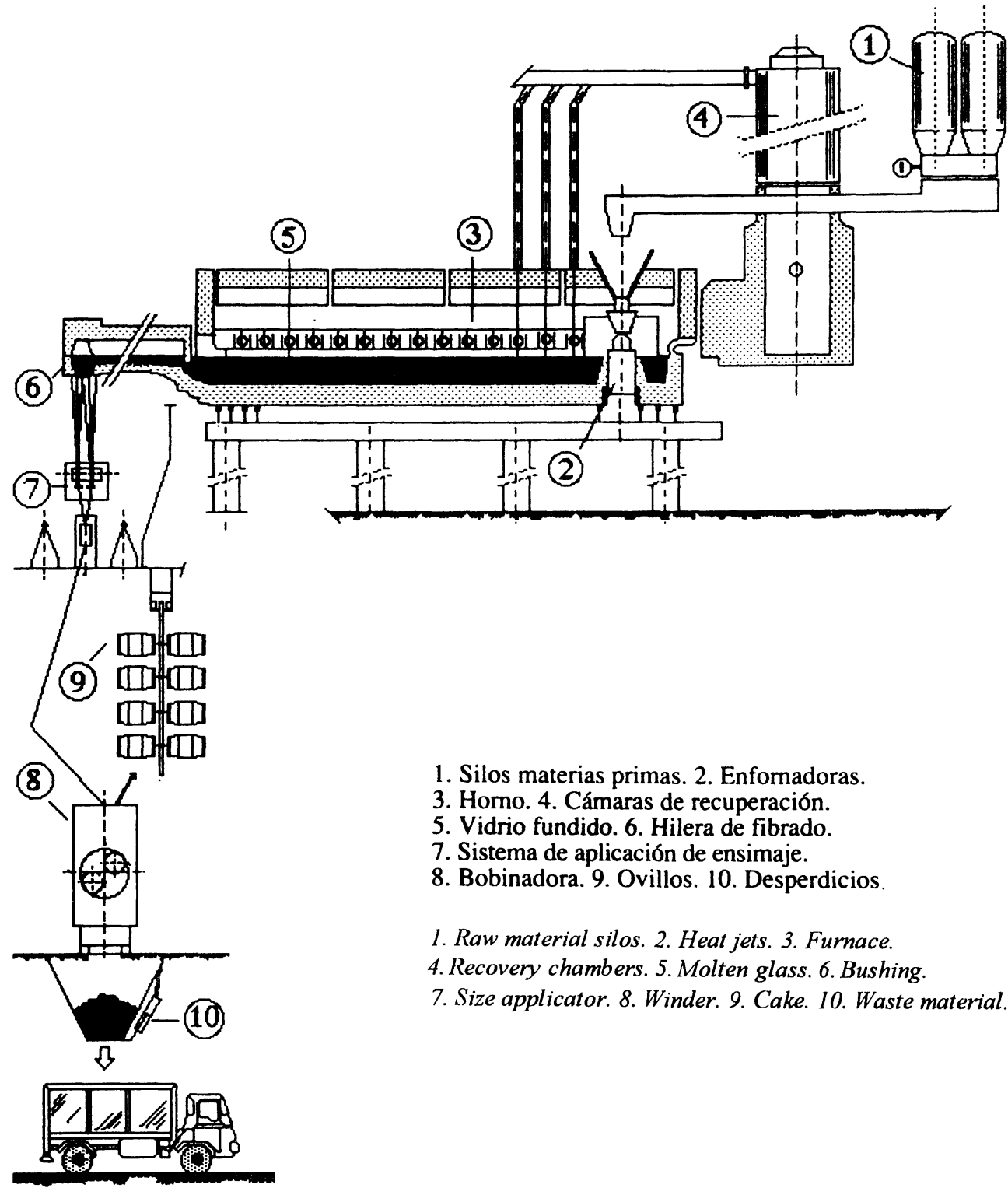

Fig. 1.- Fibrado de vidrio por fusión directa.

Fig. 1.- Glass fibre drawing by direct fusion. 


\section{FABRICACIÓN DE UN GRC}

\subsection{Elementos constituyentes}

La matriz del GRC es, normalmente, un mortero de Cemento Portland y arena silícica, amasado con una proporción controlada de agua y aditivos. La Fibra de Vidrio Cem-FIL se agrega en proporciones controladas, determinadas por la aplicación y la resistencia a otorgar a las piezas de GRC. Los componentes más usuales de un GRC son: Cemento, Arena, Agua, Fibras de Vidrio AR Cem-FIL y Aditivos.

Bajo la descripción general de GRC hay numerosas posibilidades de variar las mezclas, dependiendo del uso del producto final o del método de fabricación elegido para producir una familia de compuestos. La estandarización está más arraigada en las mezclas empleadas sobre GRC para aplicaciones arquitectónicas $\mathrm{y}$, en concreto, las mezclas usadas en el proceso de fabricación por proyección simultánea.

\subsection{Proporciones de los materiales constituyentes}

En este apartado intentaremos exponer las relaciones de dosificación normalmente consideradas como estándar, sabiendo, en todo momento, que éstas pueden verse modificadas en cantidad ( $\mathrm{y}$, por tanto, en tantos por ciento de los materiales constituyentes del GRC), según se utilicen diferentes tipos, procedencias o hasta incluso marcas de cemento, arenas y aditivos.

Las relaciones más importantes a tener en cuenta son:

Relación Arena/Cemento $\rightarrow 1: 1$

Relación Agua/Cemento $\longrightarrow$ entre 0,30 y 0,35

Superplastificante o fluidificante $\rightarrow$ Aprox. $1 \%$ del peso del cemento.

La cantidad de fibra de vidrio dependerá:

\section{Del proceso de fabricación del GRC}

Dependiendo del proceso de fabricación del GRC tendremos variaciones en la cantidad de fibra añadida. Esto es, si nuestro proceso es el de Proyección Simultánea (uso de la Fibra en forma de Roving), la cantidad de Fibra de Vidrio Álcali-Resistente Cem-FIL será del $5 \%$ en peso del total de la mezcla realizada para la fabricación del GRC. Del mismo modo, si en nuestro proceso de fabricación hemos de incorporar la fibra de vidrio durante el proceso de amasado del mortero (premezcla o premix), la proporción será del $3 \%$ del total de la mezcla realizada.

\section{MANUFACTURING A GRC}

\subsection{Base elements}

GRC is normally set in Portland Cement mortar and silica sand, mixed with a controlled proportion of water and additives. The Cem-FIL Glass Fibre is added in controlled proportions determined by the application and the resistance intended for the GRC pieces. The most usual components of a GRC are: cement, sand, water, Cem-FIL AR glass fibre and additives.

Under the general description of GRC, there are numerous possibilities of varying the mixtures depending on the use of the final product or the manufacturing method chosen to produce a family of compounds. Standardization is more deep rooted in mixtures of GRC for architectural applications, specifically the mixtures used in the simultaneous projection manufacturing process.

\subsection{Proportions of the base materials}

The aim of this section is to describe the dosage ratios normally taken as standard, although one knows that these may be altered at any time, in quantity (and thus percentages of base materials forming the GRC). depending on the use of different types, origins or even brands of cement, sand and additives.

The most important ratios to take into account are:

Sand/cement ratio $\rightarrow 1: 1$

Water/cement ratio $\rightarrow$ between 0.30 and 0.35

Superplastic or fluid mix $\rightarrow$ approx. $1 \%$ of cement weight

The amount of glass fibre will depend on:

\section{The manufacturing process of the GRC}

Depending on the manufacturing process of the GRC. there will be variations in the quality of the fibre added. That is if the process is simultaneous projecting (use of the fibre in Roving form) the quantity of CemIIL Alkali Resistant Glass Fibre will be 5\% of the total weight of the mix made to manufacture the GRC.

Likewise, if the glass fibre is to be included during the process of mixing the mortar (premix), the proportion would be $3 \%$ of the total mix made. 


\section{De la aplicación}

Las Fibras de Vidrio Cem-FIL pueden ser incorporadas entre el $0,1 \%$ y el $5 \%$ en peso.

Cuando la proporción es baja, las fibras Cem-FIL minimizan la segregación de materiales y evitan las microfisuraciones de las piezas fabricadas con cemento, aumentando la dureza y la resistencia a los choques.

Cuando las proporciones se presentan entre el $1 \%$ y el $2 \%$, las fibras Cem-FIL son ideales para mezclas armadas, reduciendo la densidad de productos de hormigón.

Cuando la proporción está entre el $2 \%$ y el 3,5\%, las fibras Cem-FIL sirven de refuerzo primario en productos realizados por moldeo y vibración de bajo coste.

Cuando la proporción es de un 5\%, se utilizan las fibras Cem-FIL para las aplicaciones que exigen una gran resistencia, tales como los paneles de fachada arquitectónicos.

\section{La resistencia a otorgar al GRC}

La cantidad de Vidrio Alcali-Resistente en forma de fibras es muy importante desde el punto de vista de la resistencia que presenta el Elemento Compuesto GRC. También es importante tener en cuenta la longitud de las fibras para la consecución de unos adecuados niveles de resistencia.

\subsection{Procesos de fabricación}

Los procesos de fabricación más utilizados hoy en día son el de la Proyección Simultánea y el de Colado Vibrado o Premezcla..

\subsection{El curado}

El proceso de curado es una de las partes más críticas en la realización de un GRC. Se ha de prestar mucha atención a la consecución de las condiciones óptimas de curado del GRC para garantizar, de esta forma, los niveles de resistencia adecuados y diseñados en el proyecto.

\section{CARACTERÍSTICAS MECÁNICAS, FÍSICAS Y QUÍMICAS DE UN GRC}

En este punto veremos los niveles de resistencias adquiridos por un GRC a los 28 días. Todos los valores corresponden a placas de espesor normal $(10 \mathrm{~mm})$ (Tablas I y II).

\section{The application}

Cem-FIL Glass Fibre between $0.1 \%$ and $5 \%$ of the weight may be included.

When the proportion is low, the Cem-FIL fibres minimize segregation of the materials and prevent micro-craks between the pieces manufactured with cement, increasing its hardness and shock resistance.

When the proportions are between $1 \%$ and $2 \%$, the Cem-FIL fibres are ideal for reinforced mixes. reducing the density of the concrete products:

When the proportions are between $2 \%$ and $3 \%$, the Cem-FIL fibres act as a primary reinforcement in mould formed and low cost vibration products.

When the proportion is 5\%, the Cem-FIL fibres are used for applications that require great resistance, such as architectural facade panels.

\section{The resistance the GRC must be provided}

The amount of Alkali Resistant Glass Fibre in fibre form is very important from the point of view of resistance in the GRC' Composite Element, but it is also important to take into account the length of the fibres to achieve adequate resistance levels.

\subsection{Manufacturing processes}

The manufacturing processes that are most used nowadays are simultaneous projection and vibrating sieving or premix.

\subsection{Curing}

The curing process is one of the most critical stages of making GRC. Great attention must be paid to achieving optimum curing conditions in the GRC to thus guarantee the adequate resistance levels set in the project.

\section{MECHANICAL, PHYSICAL AND CHEMICAL CHARACTERISTICS OF A GRC}

The following tables shows the resistance levels acquired by a GRC in 28 days. All the values are for sheets of $10 \mathrm{~mm}$. nominal thickness (Tables I and II). 
TABLA I (TABLE I)

RESISTENCIAS MECÁNICAS (a los 28 días)

MECHANICAL RESISTANCES (after 28 days)

\begin{tabular}{|c|c|c|c|}
\hline & $\begin{array}{l}\text { Unidades } \\
\text { (Units) }\end{array}$ & $\begin{array}{l}\text { PROYECCIÓN } \\
\text { (Manual o Automática) } \\
\text { PROJECTION } \\
\text { (Manual or automatic) }\end{array}$ & $\begin{array}{c}\text { PREMEZCLA } \\
\text { (Colado-Vibrado o proyección) } \\
\text { PREMIX } \\
\text { (Sieving-Vibrating or projection) }\end{array}$ \\
\hline $\begin{array}{l}\text { Fibra Cem-Fil (\%en peso) } \\
\text { (Cem-FIL Fibre) }\end{array}$ & $\%$ & 5 & 3 \\
\hline \multicolumn{4}{|l|}{ Flexión (Bending) } \\
\hline $\begin{array}{l}\text { Módulo de rotura } \\
\text { (Ultimate Strenght (MOR)) }\end{array}$ & $\mathrm{MPa}$ & $20-30$ & $10-14$ \\
\hline $\begin{array}{l}\text { Límite elástico } \\
\text { (Elastic limit (LOP) }\end{array}$ & $\mathrm{MPa}$ & $7-11$ & $5-8$ \\
\hline \multicolumn{4}{|l|}{ Tracción (Tensile) } \\
\hline $\begin{array}{l}\text { Módulo de rotura } \\
\text { (Ultimate Strenght (UTS)) }\end{array}$ & $\mathrm{MPa}$ & $8-11$ & $4-7$ \\
\hline $\begin{array}{l}\text { Límite elástico } \\
\text { (Elastic limit (BOP)) }\end{array}$ & $\mathrm{MPa}$ & $5-7$ & $4-6$ \\
\hline \multicolumn{4}{|c|}{ Resistencia al esfuerzo cortante (Shear) } \\
\hline $\begin{array}{l}\text { Resistencia interlaminar } \\
\text { (Interlaminar Strenght) }\end{array}$ & $\mathrm{MPa}$ & $3-5$ & \\
\hline $\begin{array}{l}\text { Resistencia en el plano } \\
\text { (In-plane Strenght) }\end{array}$ & $\mathrm{MPa}$ & $8-11$ & $4-7$ \\
\hline $\begin{array}{l}\text { Resistencia a la compresión } \\
\text { (Compressive Strenght) }\end{array}$ & $\mathrm{MPa}$ & $50-80$ & $40-60$ \\
\hline $\begin{array}{l}\text { Resistencia al choque } \\
\text { (Impact Strenght) }\end{array}$ & $\mathrm{Kj} / \mathrm{m}^{2}$ & $10-25$ & $10-15$ \\
\hline $\begin{array}{l}\text { Módulo de elasticidad } \\
\text { (Elastic modulus) }\end{array}$ & $\mathrm{OPa}$ & $10-20$ & $10-20$ \\
\hline $\begin{array}{l}\text { Deformación a la rotura } \\
\text { (Strain to failure) }\end{array}$ & $\%$ & $0,6-1,2$ & $0,1-0,2$ \\
\hline $\begin{array}{l}\text { Densidad del manterial } \\
\text { (Dry density) }\end{array}$ & $\mathrm{T} / \mathrm{m}^{3}$ & $1,9-2,1$ & $1,8-2,0$ \\
\hline
\end{tabular}

* Tanto la resistencia como la durabilidad del GRC pueden verse mejoradas muy notablemente gracias a la adición de un tipo de metacaolín específico. Las propiedades del GRC pueden verse mejoradas con la adición de polímeros acrílicos. Los datos expuestos se aplican a formulaciones de GRC, con una relación arena/cemento entre 0,5 y 1 .

* IThe resistance as well as the durability of the GRC may be ost considerably improved by adding specific type of metakaolin. The properties of the GRC may be improved by adding acrylic polymers. The data provided applies to GRC formulae with a send/cement ratio between 0,5 and 11 . 
TABLA II (TABLE II)

Propiedades Físicas y Químicas del GRC (Physical and Chemical Properties of GRC)

\begin{tabular}{|c|c|c|}
\hline Densidad del Material (Dry density) & $\mathrm{T} / \mathrm{m}^{3}$ & $178-2,3$ \\
\hline \multicolumn{3}{|l|}{ Pesos aproximados (Approximate weights) } \\
\hline Lámina simple $8 \mathrm{~mm}$ de espesor (Single sheet $8 \mathrm{~mm}$ thick) & $\mathrm{kg} / \mathrm{m}^{2}$ & 16 \\
\hline $\begin{array}{l}\text { Lámina simple } 12 \mathrm{~mm} \text { de espesor } \\
\text { Single sheet } 12 \mathrm{~mm} \text { thickl }\end{array}$ & $\mathrm{kg} / \mathrm{m}^{2}$ & 24 \\
\hline Panel Sand wich $(*)$ (Sandwich panel $(*))$ & $\mathrm{kg} / \mathrm{m}^{2}$ & 44 \\
\hline Retracción irreversible (Inversible retraction) & $\%$ & 0,05 \\
\hline Retracción final (Final retraction) & $\%$ & 0,2 \\
\hline $\begin{array}{l}\text { Coeficiente de dilatación térmica } \\
\text { (Thermal dilation coeficient) }\end{array}$ & $\mathrm{mm}^{\circ} \mathrm{C}$ & $10-20 \times 10^{-6} /{ }^{\circ} \mathrm{C}$ \\
\hline $\begin{array}{l}\text { Coeficiente de conductividad térmica } \\
\text { (Thermal conductivity coefficient) }\end{array}$ & $W / M^{\circ} \mathrm{C}$ & $0,5-1$ \\
\hline Resistencia química (Chemical resistance) & & Buena (Good) \\
\hline Resistencia a los sulfatos (Resistance to sulphates) & & $\begin{array}{l}\text { Se usan cementos especiales } \\
\text { Special cement used) }\end{array}$ \\
\hline Ambiente marino (Marine atmosphere) & & $\begin{array}{c}\text { No afecta propiedad. mecánicas } \\
\text { (Does not affect mechanical } \\
\text { properties) }\end{array}$ \\
\hline $\begin{array}{l}\text { Hielo-deshielo (BS4264 - DIN274) } \\
\text { (Freezing-thawing (BS4264 - DIN274) }\end{array}$ & & Ningún cambio (No change) \\
\hline \multicolumn{3}{|l|}{ Permeabilidad al vapor de agua (Steam permeability) } \\
\hline $\begin{array}{l}\text { BS } 3177 \text { para } 10 \mathrm{~mm} \text { de GRC } \\
\text { (BS } 3177 \text { for } 10 \mathrm{~mm} \text { of } G R C)\end{array}$ & $\begin{array}{l}\text { Perms. métricos } \\
\text { (Metric perma.) }\end{array}$ & $<1,3$ \\
\hline Luz ultravioleta (U/traviolet light) & & No lo degrada (Does not degrade it) \\
\hline \multicolumn{3}{|l|}{ Acústica - Reducción de $\mathrm{dB}$ (Acoustics - $d B$ reduction) } \\
\hline $\begin{array}{l}\text { Lámina de GRC de } 10 \mathrm{~mm} \text { espesor } \\
(10 \mathrm{~mm} \text { thick GRC sheet) }\end{array}$ & $d B$ & 30 \\
\hline $\begin{array}{l}\text { Lámina de GRC de } 20 \mathrm{~mm} \text { espesor } \\
(20 \mathrm{~mm} \text { thick GRC sheet) }\end{array}$ & $\mathrm{dB}$ & 35 \\
\hline $\begin{array}{l}\text { Sand wich de } 10 \mathrm{~cm} \text { (núcleo P. Exp.) } \\
10 \mathrm{~cm} \text { sandwich (Styr. core) }\end{array}$ & $\mathrm{dB}$ & 47 \\
\hline \multicolumn{3}{|l|}{ Aislamiento térmico (Thermal insulation) } \\
\hline $\begin{array}{l}\text { Lámina simple } 8 \mathrm{~mm} \text { de espesor } \\
\text { (Single sheet } 8 \mathrm{~mm} \text { thick) }\end{array}$ & $\mathrm{W} / \mathrm{m}{ }^{\circ} \mathrm{C}$ & 5,3 \\
\hline $\begin{array}{l}\text { Lámina simple } 12 \mathrm{~mm} \text { de espesor } \\
\text { (Single sheet } 12 \mathrm{~mm} \text { thick) }\end{array}$ & $\mathrm{W} / \mathrm{m}^{\circ} \mathrm{C}$ & 5,2 \\
\hline Panel Sand wich $\left({ }^{*}\right)$ (Sandiwich panel $(*)$ & $\mathrm{W} / \mathrm{m}^{\circ} \mathrm{C}$ & 0,4 \\
\hline
\end{tabular}

* El panel sandwich, en este caso, se compone de una lámina de GRC de $10 \mathrm{~mm}$ de espesor, una capa de poliestireno expandido de $110 \mathrm{~mm}$, y otra capa de GRC de $10 \mathrm{~mm}$ de espesor.

* (The sandwich panel in this case is comprised of a sheet of GRC $10 \mathrm{~mm}$. thick, a $110 \mathrm{~mm}$. sheet of styrofoam and another $10 \mathrm{~mm}$. thick shett of $G R C$ ) 


\section{VENTAJAS COMPETITIVAS DEL GRC}

La mayor de las ventajas que presenta el GRC es su reducido peso (del orden de entre $1 / 3$ y $1 / 10$ del peso de elementos equivalentes en Hormigón Convencional), guardando las mismas o superiores prestaciones.

Esta ventaja de ligereza va a repercutir, positivamente, sobre diferentes factores de diseño e instalación de las piezas y/o estructuras que soporten el GRC y de las mismas instalaciones (puesta en obra) de las piezas realizadas con este material. Los principales factores que pueden verse modificados con notables ahorros de costes son:

* Transporte de las piezas a obra.

* Estructura y Cimentaciones del Edificio.

* Maquinaria de instalación y puesta en obra.

* Cuadrillas de montaje.

* Anclajes y herrajes de unión a los entramados de la estructura.

* El montaje es mucho más rápido.

Todos estos factores de ahorro, estudiados en su conjunto, suponen una grandísima ventaja competitiva del GRC y lo convierten en líder frente a otros materiales alternativos.

\section{CUALIDADES DEL GRC}

Las fibras de vidrio tienen excelentes propiedades, que hacen de ellas el refuerzo ideal para los materiales compuestos de matriz inorgánica. Cem-FIL es la fibra idónea, por resistencia alcalina, por su alto rendimiento y por sus altas prestaciones, para el refuerzo de los composites (materiales compuestos) de cemento.

Las principales cualidades que las fibras Cem-FIL confieren al GRC son:

* Total perdurabilidad.

* Alta resistencia a la tracción y flexión.

* Gran resistencia al impacto.

* Impermeabilidad.

* Resistencia a los agentes atmosféricos.

* El GRC no se corroe ni se corrompe.

* Incombustibilidad.

* Aptitud de reproducción de detalles de superficie.

* Ligero

* Aptitud a ser moldeado en formas complejas.

* Gran resistencia contra la propagación de fisuras.

* Reduce la carga en los edifícios.

* Reduce los cuidados de mantenimiento

* Excelente resistencia frente al vandalismo.

* Enorme catálogo de texturas y acabados de superficie realizables.

* Ilimitadas posibilidades de diseños arquitectónicos.

\section{COMPETITIVE ADVANTAGES OF GRC}

The greatest advantage of (IRC' is its light weight (between 1/3 and 1/10th of the weight of equivalent materials in conventional concrete) with the same or superior features.

This advantage of lightness has a positive effect on different factors of the design and installation of the pieces and/or structures (IRC may be used in and on the assembly (on site delivery) of pieces made of the material. The main factors that may be modified are:

* 'Transport of the pieces to the site.

* Structure and foundations of the building.

* Machinery for installation and delivery on site.

* Assembly crews.

* Anchorage and joint stavs for the structure frameworks:

* Assembly is much quicker.

All of these savings factors, studied overall, give (GRC a very great competitive advantage, making it a leader compared with other alternative materials.

\section{FEATURES OF GRC}

(ilass fibres have excellent properties which make them the ideal reinforcement for materials comprised of inorganic material. ('em-FIL is the ideal fibre, due to its alkali resistance, its high performance and exceptional features in reinforcement of cement composites (composite materials).

The main features ('em-FII, fibres provide (IRC' are:

* Total durability.

* IIigh resistance to traction and flexion.

* (ireat resistance to impact.

* Impermeability.

* Resistance to atmospheric agents.

* GRC is not corroded or contaminated.

* Incombustibility.

* Fit to reproduce surface details.

* Light.

* Fit to be moulded in complex forms.

* Great resistance to propagation of fissures

* Reduces the load on buildings.

* Reduces maintenance requirements.

* Excellent resistance to vandalism.

* Vast catalogue of surface textures and finishes.

* Unlimited possibilities of architectural designs. 
En la Figura 2 se muestra un ejemplo de aplicación del GRC como panel de cerramiento. Estadio Santiago Bernabeu (Madrid).
Figure 2 shows an exact of application of GRC as a wall panel. Santiago Bernabeu Stadium, Madrid.

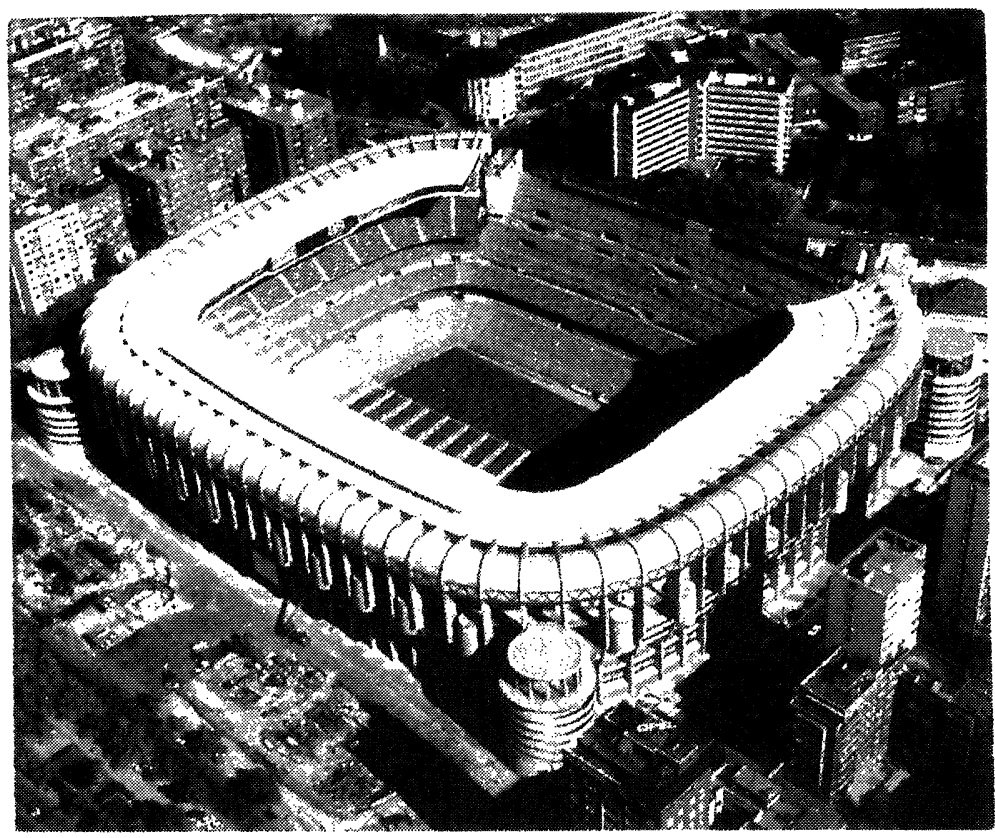

Fig. 2.- Aplicación del GRC. Fstadio Santiago Bemabeu, Madrid.

Fig. 2.- Application of CiRC. Santiago Bernabeu Stadium, Madrid.

\section{BIBLIOGRAFÍA}

(1) A.J. MAJUNDAR Y V.LAWS: "Glass Fibre Reinforced Cement"

(2) MANUAL FORTON: "Ciment Renforce de Fibres de verre"

(3) A.GENIS. J.THIERY. P.SOUKATCHOFF: "High durability Glass Cement Composites. New Vetrotex System".

(4) CEM-FIL INTERNATIONAL: "Guias de Proyección y Premezcla."

(5) CEM-FIL INTERNATIONAL: "Cem-FIL GRC Technical Data".

(6) PROF. DR. J. BIJEN: “GRC, an Ideal Building Material. Mechanical and Physical Properties".

(7) P. ANTEQUERA. L. JIMENEZ. A. MIRAVETE: "Los Materiales Compuestos de Fibra de Vidrio". 